be detected on microscopical examination, while glycogen, urea, and sone other substances may be shown to be present by chemical analysis. Not only so, but the quantity and the relative proportions of the respective constituents may be caused to vary by alterations in the food constituents. This is a matter of great interest to us, for when an organ is deranged by injudicious feeding we can in some cases, by a change in the diet for a sufficient period, and by the help of certain medicines, promote an increase or reduction in the amount of the constituents of which there may have been deficiency or excess, or we can encourage the removal of some substances from the organism and promote the retention of others. The different classes of substances formed in varying proportions such as proteids, fatty matters, salts, and carbohydrates, also vary according to the conditions under which the organism for the time lives. In some cases an organism may be caused to produce and to acoumulate fat to an enormous extent, and it may more than double in weight within a short time, or, on the other hand, the animal may be kept lean and highly active-in fact, its muscular and nerve power may be increased and thus it may be made to perform work which would have been impossible if a large proportion of adipose tissue existed. But neither of these processes-the formation of fat or its removal-could be brought about in the absence of a special power operating in living things only, the increase of adipose tissue as well as its removal being effected by living matter. And we must bear in mind that the too rapid removal of the fat of adipose tissue by great shanges in diet may endanger life.

Physiological and pathological phenomena include vital actions and depend upon vitality. They are not to be imitated or to be adeqately explained by physics or chemistry in the present state of knowledge. We must in all cases admit the operation of a power communicated by pre-existing living matter to non-living matter of a certain composition and in a certain condition. Thus has the earth been peopled by successive generations of countless living forms of the most different kinds, all of which and at every period of existence have been dependent upon vitality, being also subject to pathological changes and various forms of disease.

\section{TWENTY-FIVE CONSECUTIVE CASES STRANGULATED HERNIA; ONE DEATH. ${ }^{1}$}

BY W. THELWALL THOMAS, F.R.C.S. ENG.,

GOXORARY ASSTSTANT SURGRON TO THE ROYAL INFIRMARY, ITVERPOOL; DEMONSTRATOR OF SURGERY AND SURIXICAL PATHOLOGY, ONIYERSITY COLLKGE, LIVERPOOL.

DURING the last few years it has fallen to my lot to operate on 25 cases of strangulated hernia, of which only 1 died as a direct result of the operation. To simplify this paper I have appended a table of the cases. Twelve occurred in men, and 13 in women. The ages varied from twenty-six to seventy-eight years, 6 being over sixty and 3 over seventy years. The period of strangulation varied from ten hours (cases Nos, 11 and 22) to five days (case No. 16). The bowel in 1 case (No. 16) was greenish and had a putrid smell, but retained its shiny appearance. The omentum was gangrenous in Case 20 and the fluid in the sac, of course, decomposed and was very offensive, although the bowel looked alive, and recovered. The bowel alone was present in 9 cases; the bowel with omentum was present in 12 cases ; and the omentum alone was present in 2 cases. Omentum was removed in 11 cases; the portion removed varied from a "mere tag," in Case 18, to a pound, in Case 10. Omentum formed a complete sac, adherent universally to the peritoneum, in Case 24, an umbilical hernia, and contained a large loop of strangulated small bowel. In Case 14 there were 3 hæmorrhages in the omentum, one of which looked at first sight like a knuckle of intestine. In Case 15 there was diffuse cellulitis of the abdominal wall, with sloughing of the convexity of the sac; all the sloughs

1 A paper read at the Liverpool Medical Institution on Jan. 3 Cth, 2896. were cut away, and the tissues swabbed with pure carbolic acid (the bowel being protected) before dividing the constriction, so that neither putridity nor acid could enter the abdominal cavity. This was of course a very serious complication, but the woman recovered with a fæcal fistula. The bladder was present alongsids a strangulated right inguinal hernia in Case 25 , a very rare occurrence. Up to 1893 only 59 cases had occurred in surgical literature, and Macready ${ }^{3}$ had only been able to collect 36 cases.

Details of procedure. Chloroform was used as an anæsthetic in every case, although in Case 10 only a few whiffs were given, the patient being deeply cyanosed from a very acute attack of bronchitis. His knees were strapped down and his hands held whilst the skin incision was rapidly made. He was by no means "under chloroform." The anæsthetic was laid aside and the remainder of the operation conducted with the man conscious, and he experienced no pain during the necessary manipulation of the sac, intestine, and the removal of a pound of omentum; but when the sutures were being passed through the skin bis language was "frequent and painful and free." In Case 20 , an old man aged seventy - six years, with chronic bronchitis and emphysema, was operated upon propped up in bed with four pillows. Mr. Caregan administered a few drops of chloroform; with my left elbow I kept the patient's knee down and held a dissecting forceps in my left hand, the knife being in the right. The operation was quickly completed; it necessitated the removal of two pieces of gangrenous omentum, the return of the bowel, the ligature of the sac, and the introduction of only one suture in the skin. Both these cases recovered without a bad symptom. In all the operations speed was particularly cultivated and I believe had much to do with the happy result.

Treatment of the contents of the sac.-Investigations have demonstrated the poisonous nature of the fluid found in the sac of strangulated hernia. I need only quote Nepveu and Garré, ${ }^{1}$ who found bacteria, and these did not appear to bear any relation to time or degree of strangulation (putridity apparent to the sense of smell being no guide). Clado, inoculated animals with fluid from the sac of a strangulated hernia. The animals died, and the organisms were found in the blood, spleen, lungs, and the serous cavities. $\mathrm{He}$ considers death in strangulated hernia due to the introduction of organisms from the intestinal tract into the general circulation. This position is strengthened when we bear in mind that abou 10 per cent. die when the strangulated hernia is reduced by taxis. Benno Schmidt ${ }^{6}$ considers the field of operation in strangulated hernia already septic. Bearing in mind these and similar statements by many investigators, special attention was paid to disinfection of the sac contents as soon as opened and before any attempt at reduction. This was always carried out by freely washing the fluid away with hot 1 in 40 carbolic lotion, until every shred of lymph and blood-stained material was thoroughly removed from amongst the coil or coils of intestine and the interstices of the omentum when present. When it was decided to remove omentum a fresh portion was dragged down and this ligatured and divided, when the piece in the sac, being now deprived of its blood-supply, could be forcibly torn away, if adherent, without risk of hæmorrhage. This methcd materially aids rapidity of procedure.

Radical cure. - In the worst cases, and in the old people, Czerny's radical cure, simple ligature of the neck of the sac, was performed, Macewen's method being used in the younger patients and in those cases where urgency was not so imperative and a more certain radical cure indicated. Two cases (Nos. 4 and 17) had congenital inguinal sacs, and the portion cut off for a tunica vaginalis was closed with a continuous catgut suture.

Treatment of nound.-Silkworm gut sutures, double cyanide gauze under wood wool tissue, and a suitable bandage or binder were used. In only two were there wound complications-Case 15, where a fæcal fistula formed, and Case 25, where the wound suppurated, necessitating the reopening of the inguinal canal. This was due to contamination with ammoniacal urine from a hernia of the bladder, which complicated the case. It occurred in a man aged fiftynine years, who was admitted into the infirmary for strangulated hernia, and operated upon at once (11.30 P.M.). He

2 Deutsche Zeitschrift fur Ohirurgie, Leipzig, 1893, p. 301. Ruptures, Macready.

4 Centralblatt tur Chirurgie. No. 50, p. 859.
5 Revue de Chirurgie, 1889 , p. 967.

6 Berliner Klinische Wochenschrift, 1883, p. 308. 
Twenty-five Consecutive Cases of Strangulated Hernia.

\begin{tabular}{|c|c|c|c|c|c|c|c|c|c|c|}
\hline 宗 & $\stackrel{\substack{0 \\
4}}{4}$ & $\underset{\Phi}{\stackrel{x}{\infty}}$ & $\begin{array}{l}\text { Where operated, } \\
\text { and date. }\end{array}$ & $\begin{array}{l}\text { Doctor's } \\
\text { case. }\end{array}$ & $\begin{array}{l}\text { Variety } \\
\text { of } \\
\text { hernia. }\end{array}$ & $\begin{array}{l}\text { Strangu- } \\
\text { lated } \\
\text { time. }\end{array}$ & Contents of sac. & $\begin{array}{l}\text { Condi- } \\
\text { tion of } \\
\text { bowel. }\end{array}$ & Details of operation. & Result: \\
\hline 1 & 58 & M. & $\begin{array}{l}\text { Ormskirk Workhouse, } \\
\text { Dec. 19th, } 1891 .\end{array}$ & Mr. Anderton. & $\begin{array}{l}\text { Right } \\
\text { serotal. }\end{array}$ & 2 dass. & $\begin{array}{c}8 \text { inches of bowel and } \\
\text { omentum. }\end{array}$ & $\begin{array}{l}\text { Dark } \\
\text { purple. }\end{array}$ & $\begin{array}{l}4 \text { oz. of omentum re- } \\
\text { moved; Ball's radical } \\
\text { cure. }\end{array}$ & Cured. \\
\hline 2 & 30 & M. & $\begin{array}{c}\text { Liverpool Royal Infir- } \\
\text { mary, Nov.12th, } 1892 .\end{array}$ & - & $\underset{\text { inguinal. }}{\text { Right }}$ & $?$ & Loop of the bowel. & $\begin{array}{l}\text { Dark } \\
\text { purple. }\end{array}$ & $\begin{array}{c}\text { Ligature of the neck of } \\
\text { the sac. }\end{array}$ & Do. \\
\hline 3 & 76 & M. & $\begin{array}{c}\text { Wavertree, Nov. 26th, } \\
1892 .\end{array}$ & Dr. O'Hagan. & $\begin{array}{c}\text { Left } \\
\text { scrotal. }\end{array}$ & 2 days. & $\begin{array}{l}4 \text { inches of bowel, } \\
\text { omentum congested } \\
\text { and hamorrhagic, } \\
\text { blood-stained serum } \\
20 \% \text {. }\end{array}$ & $\begin{array}{l}\text { Dark } \\
\text { purple. }\end{array}$ & $\begin{array}{l}\text { The ring was incised; } \\
\text { neck of the sac liga- } \\
\text { tured. }\end{array}$ & Died. \\
\hline 4 & 26 & M. & $\begin{array}{l}\text { Liverpool Royal Infir- } \\
\text { mary, Jan. 8th, } 1893 .\end{array}$ & 一 & $\begin{array}{l}\text { Right } \\
\text { scrotal. }\end{array}$ & 19 hours. & $\begin{array}{l}6 \text { inches bowel ; con- } \\
\text { genital sac strangu- } \\
\text { lation by external } \\
\text { ring; bowel in canal } \\
\text { normal. }\end{array}$ & $\begin{array}{c}\text { Dark } \\
\text { pürple. }\end{array}$ & $\begin{array}{c}\text { The sac was divided; the } \\
\text { tunica vaginalis was } \\
\text { sutured for testicle; } \\
\text { the neck was ligatured. }\end{array}$ & Cureä: \\
\hline 5 & 69 & F. & $\begin{array}{l}\text { Private house, June } \\
\text { 5th, 1893, 12.30 A.M. }\end{array}$ & $\begin{array}{l}\text { Mr. Edwards, } \\
\text { Anfield. }\end{array}$ & $\begin{array}{c}\text { I.eft } \\
\text { femoral. }\end{array}$ & 3 days. & $\begin{array}{c}\text { "Large knuckle" (no } \\
\text { omentum). }\end{array}$ & $\begin{array}{c}\text { Dark } \\
\text { purple. }\end{array}$ & $\begin{array}{l}\text { Gimbernat's ligament } \\
\text { was incised and the neck } \\
\text { of the sac ligatured. }\end{array}$ & Do. \\
\hline 6 & 36 & M. & $\begin{array}{l}\text { Liverpool Royal Infir- } \\
\text { mary, June 25th, } 1893 \text {. }\end{array}$ & - & $\begin{array}{c}\text { Right } \\
\text { inguinal. }\end{array}$ & 3 days. & $\begin{array}{l}\text { About } 4 \text { inches of } \\
\text { bowel. }\end{array}$ & $\begin{array}{l}\text { Dark } \\
\text { purple. }\end{array}$ & $\begin{array}{l}\text { The sac was ligatured } \\
\text { (funicular process). }\end{array}$ & Do. \\
\hline 7 & 61 & F. & $\begin{array}{l}\text { Liverpool Royal In- } \\
\text { firmary, July } 28 \text { th, } \\
\text { l893. }\end{array}$ & - & $\begin{array}{c}\text { Left } \\
\text { femoral. }\end{array}$ & $\begin{array}{c}\text { Obstructed. } \\
\text { going on } \\
\text { to stran- } \\
\text { gulation, } \\
1 \text { week. }\end{array}$ & $\begin{array}{l}\text { Knuckle of bowel, } \\
\text { mass of omentum. }\end{array}$ & $\begin{array}{l}\text { Dark } \\
\text { purple. }\end{array}$ & $\begin{array}{c}\text { Gimbernat's ligament } \\
\text { was nicked. The neck } \\
\text { of the sac was ligatured } \\
\text { and omentum removed. }\end{array}$ & Dox $_{2}$ \\
\hline 8 & 78 & F. & $\begin{array}{l}\text { Private house, } \\
\text { Oct. 20th, 1893. }\end{array}$ & $\begin{array}{l}\text { Mr. Laing, } \\
\text { Burscough. }\end{array}$ & $\begin{array}{c}\text { Left } \\
\text { femoral. }\end{array}$ & 2 days. & $\begin{array}{l}\text { Knuckle oî bowel, } \\
\text { flakes of lymph. }\end{array}$ & $\begin{array}{c}\text { Dark } \\
\text { purple. }\end{array}$ & $\begin{array}{l}\text { Reduced without in- } \\
\text { cision of the neck; } \\
\text { ligature of the sac. }\end{array}$ & Do. \\
\hline 9 & 30 & F. & $\begin{array}{l}\text { Liverpool Royal Infir- } \\
\text { mary, Oct. } 28 \mathrm{th}, 1893 .\end{array}$ & - & $\begin{array}{l}\text { Left } \\
\text { femoral. }\end{array}$ & - & $\begin{array}{l}5 \text { inches bowel and } \\
\text { adherent omentum. }\end{array}$ & $\begin{array}{l}\text { Dark } \\
\text { purple. }\end{array}$ & Removal of omentum. & Dow \\
\hline 10 & 43 & $\mathbf{M}$ & $\begin{array}{l}\text { Liverpool Royal In- } \\
\text { firmary, April 14tb, } \\
1894 .\end{array}$ & 一 & $\begin{array}{l}\text { Umbili- } \\
\text { cal. }\end{array}$ & 2 days. & $\begin{array}{l}4 \text { inches small gut and } \\
\text { omentum. }\end{array}$ & $\begin{array}{l}\text { Dark } \\
\text { purple. }\end{array}$ & $\begin{array}{l}1 \text { lb. of omentum re- } \\
\text { moved; neek of sac } \\
\text { tied. }\end{array}$ & Don \\
\hline 11 & 34 & M. & $\begin{array}{l}\text { Liverpool Royal In- } \\
\text { firmary, April 23rd, } \\
\text { 1894. }\end{array}$ & 一 & $\begin{array}{l}\text { Right } \\
\text { inguinal. }\end{array}$ & 10 hours. & - & - & - & Do: \\
\hline 12 & 58 & F. & $\begin{array}{l}\text { Liverpool Royal In- } \\
\text { firmary, April 12th, } \\
\text { 1894. }\end{array}$ & - & $\begin{array}{c}\text { Left } \\
\text { femoral. }\end{array}$ & 24 hours. & $\begin{array}{l}\text { 2.1 inches of intestine } \\
\text { and omentum. }\end{array}$ & $\begin{array}{l}\text { Dark } \\
\text { purple. }\end{array}$ & $\begin{array}{l}\text { Removal of onentum; } \\
\text { ligature of the neck. }\end{array}$ & $D_{0 .}$ \\
\hline 13 & 39 & M. & $\begin{array}{l}\text { Liverpool Roval In- } \\
\text { firmary, April 29th, } \\
\text { 1894. }\end{array}$ & Mr. Dunn. & $\begin{array}{c}\text { Right } \\
\text { inguinal. }\end{array}$ & 12 hours. & 3 inches of intestine. & $\begin{array}{l}\text { Dark } \\
\text { purple. }\end{array}$ & Macewen's radical cure. & Do. \\
\hline 14 & 52 & F. & $\begin{array}{l}\text { Liverpool Royal In- } \\
\text { firmary, May 6th, } \\
\text { 1894. }\end{array}$ & 一 & $\begin{array}{l}\text { Left } \\
\text { femoral. }\end{array}$ & 2 days. & $\begin{array}{l}\text { Omentum only, with } 3 \\
\text { blood cysts (simu- } \\
\text { lated bowel!. }\end{array}$ & - & $\begin{array}{l}3 \frac{3}{4} \text { oz. of omentum } \\
\text { removed ; adherent } \\
\text { around two-thirds of } \\
\text { the orifice. }\end{array}$ & Do. \\
\hline 15 & 53 & F. & $\begin{array}{l}\text { Liverpool Royal Infir- } \\
\text { mary, Oct. 8th, } 1894 .\end{array}$ & - & $\begin{array}{c}\text { Um- } \\
\text { bilical. }\end{array}$ & 3 days. & $\begin{array}{l}\text { Loop of large bowel, } \\
\text { oment um. }\end{array}$ & $\begin{array}{c}\text { Odorous } \\
\text { but } \\
\text { shiny, } \\
\text { omen- } \\
\text { tum } \\
\text { sloughy. }\end{array}$ & $\begin{array}{l}\text { Portion of the sac re- } \\
\text { moved ; sloughy cellu- } \\
\text { lar tissue of abdomen } \\
\text { suppurating, constric- } \\
\text { tion divided, omentum } \\
\text { removed, sac tied. }\end{array}$ & $\mathrm{D}_{0}$ \\
\hline 16 & 52 & F. & $\begin{array}{l}\text { Liverpool TRoyal Infir- } \\
\text { mary, Dec. 3rd, } 1894 .\end{array}$ & 一 & $\begin{array}{l}\mathbf{U m}- \\
\text { bilical. }\end{array}$ & 5 days. & $\begin{array}{c}\text { Loop of bowel and } \\
\text { omentum. }\end{array}$ & $\begin{array}{c}\text { Dark } \\
\text { purple. }\end{array}$ & $\begin{array}{l}\text { Operation rapidìy per- } \\
\text { formed; bowel pushed } \\
\text { back. }\end{array}$ & $\begin{array}{l}\text { Died } \\
\text { same } \\
\text { night. }\end{array}$ \\
\hline 17 & 55 & M. & $\begin{array}{l}\text { Liverpool Royal In- } \\
\text { firmary, Dec. 9th, } \\
\text { 1894. }\end{array}$ & 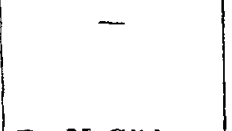 & $\begin{array}{c}\text { Left } \\
\text { inguinal. }\end{array}$ & 12 hours. & $\begin{array}{l}\text { Congenital sac, large } \\
\text { loop of bowel. }\end{array}$ & $\begin{array}{l}\text { Dark } \\
\text { purple. }\end{array}$ & $\begin{array}{l}\text { Tunica raginalis made } \\
\text { and sutured for } \\
\text { testicle. Macewen's } \\
\text { radical cure. }\end{array}$ & Cured. \\
\hline 18 & 45 & $\mathbf{F}$. & $\begin{array}{l}\text { Liverpool Royal In- } \\
\text { firmary, Jan. 14th, } \\
\text { 1895. }\end{array}$ & Dr. McGibbon. & $\begin{array}{c}\text { Left } \\
\text { inguinal. }\end{array}$ & 2 days. & Omentum only. & - & $\begin{array}{l}\text { Large amount of in- } \\
\text { flamed extra-peritoneal } \\
\text { fat removed; sactreated } \\
a \text { la Macewen; tag of } \\
\text { omentum removtd. }\end{array}$ & Do. \\
\hline 19 & 50 & F. & $\begin{array}{l}\text { Private House, } \\
\text { March 8th, } 1895 .\end{array}$ & $\begin{array}{l}\text { Mr. Laing, } \\
\text { Burscough. }\end{array}$ & $\underset{\text { inguinal. }}{\text { Right }}$ & 12 hours. & $\begin{array}{l}\text { Knuckle of bowel and } \\
\text { tag of omentum } \\
\text { adherent to sac. }\end{array}$ & $\begin{array}{l}\text { Dark } \\
\text { claret. }\end{array}$ & $\begin{array}{l}\text { Oment um removed; } \\
\text { neck of sacligatured. }\end{array}$ & Do. \\
\hline 20 & 76 & M. & $\begin{array}{l}\text { Private House, June } \\
\text { 16th, 1895. }\end{array}$ & $\begin{array}{l}\text { Mr. Caregan, } \\
\text { Ormskirk. }\end{array}$ & $\begin{array}{c}\text { Left } \\
\text { inguinal. }\end{array}$ & 2 days. & $\begin{array}{l}\text { Knuckle of bowe?; } \\
\text { sloughly omentum; } \\
\text { stinking blood- } \\
\text { stained serum. }\end{array}$ & $\begin{array}{l}\text { Dark } \\
\text { purple, } \\
\text { shiny. }\end{array}$ & $\begin{array}{l}\text { Omentum was remored; } \\
\text { the sac was well puri- } \\
\text { fied; ligature around } \\
\text { neck; one suture in } \\
\text { skin. }\end{array}$ & Do. \\
\hline 21 & 64 & F. & $\begin{array}{l}\text { Liverpool Royal In- } \\
\text { firmary, June 3Cth, } \\
1895 \text {. }\end{array}$ & Dr. Samuels. & $\begin{array}{l}\text { Right } \\
\text { femoral } \\
\text { and left } \\
\text { femoral. }\end{array}$ & $\begin{array}{l}\text { Left; } \\
24 \text { hours. }\end{array}$ & Knuckle of bowel. & $\begin{array}{l}\text { Dark } \\
\text { purple. }\end{array}$ & $\begin{array}{l}\text { Gimbernat's ligament } \\
\text { was nicked; Macewen's } \\
\text { radical cure; right } \\
\text { hernia chiefy extra- } \\
\text { peritoneal fat; no- } \\
\text { thing in sac. }\end{array}$ & Do \\
\hline 22 & 46 & F. & $\begin{array}{l}\text { Liverpool Royal In- } \\
\text { firmary, Sept., } 1895 .\end{array}$ & $\begin{array}{l}\text { Dr. Mercer, } \\
\text { Ditton. }\end{array}$ & $\begin{array}{l}\text { Right } \\
\text { femoral. }\end{array}$ & 10 hours. & $\begin{array}{l}3 \text { inches of bowel ad- } \\
\text { herent to omentum, } \\
\text { bloodstained fluid. }\end{array}$ & $\begin{array}{l}\text { Dark } \\
\text { purple. }\end{array}$ & $\begin{array}{l}\text { Gimbernat's ligament } \\
\text { was nicked : Macewen's } \\
\text { radical cure. }\end{array}$ & Do. \\
\hline 23 & 58 & M. & $\begin{array}{l}\text { Liverpool IRoyal In- } \\
\text { firmary, Sept. 26th, } \\
1895 .\end{array}$ & $\begin{array}{c}\text { Dr. Blackledge, } \\
\text { Tuebrook. }\end{array}$ & $\mid \begin{array}{c}\text { Right } \\
\text { inguinal. }\end{array}$ & 2 days. & $\begin{array}{l}2 \text { loops of about } 8 \\
\text { inches each, } 1 \text { loop } \\
\text { twisted and strangu- } \\
\text { lated. }\end{array}$ & $\begin{array}{l}\text { Dark } \\
\text { purple. }\end{array}$ & Macewen's radical cure. & Do. \\
\hline
\end{tabular}


The LANCet,] MR. W. T. THOMAS: TWENTY-FIVE CASES OF STRANGULATED HERNIA. [APRIL 11, 1896.989

Twenty-five Consecutive Cases of Strangdlated Hernia-Continued.

\begin{tabular}{|c|c|c|c|c|c|c|c|c|c|c|}
\hline$\dot{0}$ & $\underset{\dot{S}}{4}$ & $\dot{x}$ & $\begin{array}{l}\text { Where operated, } \\
\text { and date. }\end{array}$ & $\begin{array}{l}\text { Doctor's } \\
\text { case. }\end{array}$ & $\begin{array}{l}\text { Variety } \\
\text { of } \\
\text { hernia. }\end{array}$ & $\begin{array}{l}\text { Strangu- } \\
\text { lated } \\
\text { time. }\end{array}$ & Contents of sac. & $\begin{array}{l}\text { Condi- } \\
\text { tion of } \\
\text { bowel. }\end{array}$ & Details of operation. & Result. \\
\hline 27 & 38 & F. & $\begin{array}{l}\text { Liverpool Royal Infir- } \\
\text { mary, Sept. 29th, } \\
\text { 1895. }\end{array}$ & - & $\underset{\text { bilical. }}{\text { Um- }}$ & 25 hours. & $\begin{array}{l}\text { Large loop of small } \\
\text { bowel with omental } \\
\text { sac. }\end{array}$ & $\begin{array}{c}\text { Dark } \\
\text { purple. }\end{array}$ & $\begin{array}{l}\text { Omentum was dissected } \\
\text { away off sac; ligatured } \\
\text { vessel by vessel; the } \\
\text { sac was ligatured. }\end{array}$ & Cured. \\
\hline 25 & 59 & M. & $\begin{array}{l}\text { Liverpool Royal Infir- } \\
\text { mary, Oct. } 21 \text { st, } 1895 .\end{array}$ & Mr. Durlgeon. & $\begin{array}{l}\text { Right } \\
\text { inguinal } \\
\text { through } \\
\text { internal } \\
\text { ring. }\end{array}$ & 24 hours. & $\begin{array}{l}\text { Loop of bowel ; large } \\
\text { hernia of bladder } \\
\text { through back wall of } \\
\text { inguinal canal into } \\
\text { scrotum, adherent to } \\
\text { sac of hernia of } \\
\text { bowel. }\end{array}$ & $\begin{array}{c}\text { Dark } \\
\text { purple. }\end{array}$ & $\begin{array}{l}\text { Macewen's radical cure } \\
\text { on sac of hernia; the } \\
\text { bladder was replaced. }\end{array}$ & Do. \\
\hline
\end{tabular}

REMARKs.-Case 1: Slight recurrence of the hernia 6 months afterwards. The patient was a chronic bronchitic, and uses a l:ght truss now (1895). Case 2: The notes of this case are mislaid. Case 3: All the symptoms were relieved, and the patient took food. He had an enlarged prostate, cystitis, and incontinence, also ammoniacal urine requiring frequent catheterising. He died on the 6th day from coma (uræmia). 'Ihe wound was clean. Case 9: Slight recurrence of hernia in April, 1894; controlled by light truss. Case 10: The man was deeply cyanotic from bronchitis. Only a smell of chloroform was given to dull sen sation for the skin incision. He was fully awake and talking with us during the remainder of the operation. Case 11: The notes of this case are mislaid. Case 12: 3 weeks after operation suffered from attacks of colic, which pielled to starvation and opium. Case 14: Omental hernia with marked strangulation symptoms. Case 15: Recovered with fæcal fistula 6 months later after failure of att $\mathrm{mpt}$ to remove tbe "spur" Murphy's button was used, but the patient died from shock of the operation tbe same night. Case 15: Patient had feculent vomiting for 24 hours before admission; her pulse could hardlv be felt the collapse was so marked, but it was considered alvisable to attempt the operation. Case 17: Troublesome bronchitis. Case 18: Although no bowel was found during the operation, there had been absolute constipation and incessant vomiting for the 2 days. Case $20:$ The wound was left practically open. The patient was so ill from bronchitis that be could not lie down, he was in a semi-sitting position and only partially placed under chloroform. Six montbs later he died suddenly while out walking. Case 21 : Left hernia only strangulated, but the existence of an irreducible lump on the right side necessitated its exploration. Case 22 : On the third day there was some distension of the abdomen and tenderness which yielded to saline purge. Case 25: The bladder hernia was as large as a fist and surrounded by a layer of cellular tissue which formed a sac for it and which was ligatured in a bunch after reducing the bladder which had been emptied through a puncture; this puncture was closed by two rows of Lembert sutures.

In the above table 25 cases of strangulated hernia are given :-In Nos. 14 and 18 omentum only was found in the sac. Males: Inguinal right, 8; inguinal left, 3 ; and umbliral, 1 . Females: Femoral left, 7 ; femoral right 2; inguinal right, 1 ; inguinal left. 1 ; and umbilical, 3 . The ages of the males were $26,30,34,36,39,43,55,58,58,59,76$, and 76 respectively, and those of the females $30,38,45,46,50,52,52,53,58,61,64,69$, and 78 respectively. There were two deaths (one directly after operation). The first was from cystitis, nephritis, and coma on the sixth day; he had been respectively. There were two deaths (one directly after operation). The first was from cystitis, nephritis, and coma on the sixth day; he had been troubled with enlarged prostate for years; the bowel symptoms had been entirely relieved and the wound was healthy; this patient was a
male aged 76 years (No. 3). The otier was from collapse; the patient was in snch a d asperate condition that allowing her to die unrelieved male aged 70 years (No. 3). The otier was from collapse; the patient was in such a d sperate condition that allowing her to die unrelieved
was thought of ; this patient was a female aged 52 years (No.16). No. 15, a female, died six months afterwards from an attempt to repair a was thought of

was suffering from severe vomiting and pain, there being an irreducible swelling in the right groin and scrotum. On exposing the swelling it was found to consist of two parts : (1) a smaller, evidently escaping through the internal abdominal ring; this was opened and found to contain a knuckle of acutely nipped bowel, which was reduced and the sac treated $\grave{a}$ la Macewen ; and (2) a larger, the size of a man's fist, which occupied the scrotum and the lower half of the canal; it evidently contained fluid; this was explored by making a tiny puncture, when out shot ammoniacal urine. It was therefore apparent that a portion of the urinary bladder had herniated. The edges of the puncture were at once clamped, a catheter passed per urethram, and the bladder and this pouch emptied. There was now seen a thin sheet of fibrous tissue stretched over the bladder hernia which was continuous with the back wall of the inguinal canal. It was dissected up and a finger passed between it and the bladder wall into the abdominal cavity and pelvis to separate tissues and prepare a place for it. This portion of bladder had no peritoneum over it and had escaped through the usual place of a direct inguinal hernia, quite three-quarters of an inch to the inner side of the internal abdominal ring. The sides of the puncture were closed by two rows of Lembert sutures, and after some manipulation the portion of bladder returned, the fibrous sac covering which was ligatured flush with the posterior wall of the inguinal canal. The wound suppurated as before mentioned and a slough formed, which was treated by rubbing with pure carbolic acid; after this the case ran an uninterrupted course.

Treatment of casus after operation.--After the first 2 cases morphia (or opium) was not allowed. This drug, although useful for relieving pain, acts directly on the intestinal wall, paralysing it, and thus preventing the bowel acting and relieving itself of flatus and "banked-up" contents. The routine administration of opium appears to rest on the assumption that the loop of bowel after return becomes inflamed. This is of course pure theory. Acting on the idea that if the bowel is fit to return it may be left absolutely to nature unhampered by any "paralyser," I have had no reason to regret it. In only one case (No. 22) did the patient complain of pain, which came on the third day, accompanied by distension and tenderness of the abdomen. This yielded at once to the action of a smart saline purge. Complications that may arise, such as peritonitis, enteritis, and persistence of strangulation, will be materially masked by opium, which eases pain, prevents diarrhœa and vomiting, and causes distension of the abdomen.

Diet.-For the first twenty-four hours sips of warm water only, ice being prohibited, for patients and nurses say that enough ice cannot be given to quench thirst; this is probably due to the dryness and hardness of the tongue produced by the abstraction of heat to melt the ice. If flatus be not passed by the end of this time the same starvation is indulged in until it does. After the passage of flatus half a pint of beef tea is granted during the next twenty-four hours ; then, if all goes well, half a pint of milk is added the next day, increased by half a pint daily until two pints of milk and half a pint of beef-tea are reached, generally by the sixth or seventh day. The patients are kept on this until the bowels act. If by the ninth or tenth day no action of the bowels has taken place a dose of compound liquorice powder is given (sometimes an enema). The diet is now increased by the addition of fish, then beef tea, and, some of the milk being discontinued, chicken and a chop on successive days, and generally, unless any contra-indication, common diet by the end of the second week. The cases that recovered were all kept in bed for six weeks to allow of a firm cicatrix forming. In some of the older patients, particularly when much collapsed, a teaspoonful of brandy in a little warm water was given every hour for the first day, and continued if considered necessary in modified doses.

Results.-One patient died the night of the operation, and Case 16 from collapse. She had a large strangulated umbilical hernia, and was so reduced from fæcal vomiting that her pulse was hardly perceptible at the wrist; still, it was not considered right to allow an individual to die with bowel unrelieved. The operation lasted only a few minutes; there was no attempt at radical cure, merely two sutures passed through the skin and sac to close the aperture. Case 3, a man aged seventy-six years, died on the sixth day from coma gradually coming on from kidney mischief. He had enlarged prostate and cystitis with ammoniacal urine, and needed frequent catheterising. The bowel symptoms were all relieved. He was partaking freely of milk. The wound was healthy. With the usual leniency accorded to operators, this death not being counted, we can, I think, fairly place the mortality as 1 out of 25 cases-fortunately a very low figure when it is remembered that 6 were over sixty years of age (3 over 
seventy years). I conclude with the belief that the prompt recognition of the condition and early operation, without the old-fashioned savage attempts at taxis (10 of the cases were operated upon within twenty-four hours), had much to do with the low mortality. When the operation is undertaken, rapidity, thorough antiseptic cleansing of the sac contents, no undue delay over so-called radical cure, and judicious starvation without opium can be relied upon to keep the deaths down to a small percentage.

Jiverpool.

\section{VENTRO-HYSTEROPEXY}

\section{By J. O'CONNOR, M.A., M.D., B.Ch., T.C. Dub}

BLNIOR MEDICAL OFFICER, BRITISET HOSPITAL, IJUENOS ATRES.

DURING the past twelve months I have periormed abdominal fixation of the uterus for prolapse eight times, and I wish to bring more fully under the notice of the profession the ease and certainty with which this operation may be executed, also the advantages of fibro-serous approximation, so ably advocated by Mr. Greig Smith. Quite recently I had an opportunity of realising the danger in anyone attempting to fix the uterus to the anterior parietes without opening the abdominal cavity. I particularly refer to a method of intrauterine ventro-fixation recommended by $\mathrm{Mr}$. Shober. On opening the peritoneal carity, the omentum covered anteriorly the lower abdominal viscera in all directions, notwithstanding the fact that my two-inch incision extended to within half an inch of the pubes. If I had attempted to fix the uterus by a needle passed through the womb without opening the peritoneum, I certainly would have included the omentum; therefore with this experience-and I have seen the same in other cases-I have strong objections to working in the dark. In each of the eight cases there has not been the slightest post-operative complication; all united by first intention, in no instance did the temperature exceed $100^{\circ} \mathbf{F}$., and no recurrence of the trouble has been reported, and, although I never order an abdominal belt to be worn afterwards, no ventral hernia has occurred. To my mind the latter mishap is due to deficient care in suturing the parietal wound. Of course a short period only has elapsed, therefore these latter observations can onjy be tentative. In a way I feel thankful that I have not as yet been afforded the opportunity of examining the class of adbesion that takes place, nor have any of $\mathrm{my}$ patients, so far as I know, tested the same by becoming pregnant. As some of them are young doubtless the test will be applied.

The operation is carried out as follows: The patient, having been " acclimatised" to hospital life for a fortnight, during which time sundry repairs are undertaken-curetting the endometrium, excision of the cervix, and colpo-perineorraphy, the bowels, if necessary, being well cleared out with repeated doses of magnesium sulphate the day before the operation the pubic hair is shaved off and the skin of the abdomen scrubbed with soda, soap, and hot water, then washed with turpentine, and a large piece of lin soaked in a 1 in 500 solution of corrosive sublimate applied and fixed on for the night by antiseptic wool and a bandage. On the morning of the operation a large soap and water enema is given, and immediately before the patient is brought into the operating-room the urine is drawn off. The patient having been chloroformed the night's dressing is removed and the skin all round the field of operation is again scrubbed with a sponge soaked in turpentine and lastly thoroughly washed with Watson Cheyne's strong solution:-1. An incision two inches in length is made in the median line and extending to within half an inch of the pulues. All bleeding must be stopped before the peritoneum is picked up with a pair of dissecting forceps and opened; a few rressure forceps are attached to the cut edges of the periton $\mathbf{u} \mathbf{n}$-these help greatly in after manipulations. 2. 'The left index-finger is passed down below the intestines and omentum to the uterus, with palmar surface, hooking the former upwards. With the tip of the finger steadied on the womb I pass down a Muzeux forceps on the dorsal aspect of the finger, seize the uterus, and pull it up to the wound. 3. An assistant now takes hold of the forceps and the presenting surface is scarified with the point of a scalpel; some trifling oozing takes place, which is easily arrested by sponge pressure. 4. At the lower angle of the wound a curved needle threaded with silk is passed from without inwards through the rectus muscle anc transversalis fascia. The peritoneum being retracted by pressure forceps (previously applied) the needle is then passed for at least a quarter of an inch in depth into the uterus and made to emerge about half an inch from the point of entry. The peritoneum on the opposite side is next held back while the needle is passed from within outwards through the transversalis fascia and rectus muscle. In this manner three sutures at intervals of a third of an inch are inserted. Any bleeding from the needle punctures is arrested by sponge pressure. 5. The peritoneum is again held back on each side and these sutures are tied firmly and the ends cut off. (Care must be taken not to tie too tightly lest the silk sutures should cut through the uterus; firm approximation is all that is necessary.) In this manter the serous covering of the uterus is brought into intimate connexion with the transversalis fascia and recti muscles for half an inch in width and one inch in length. 6. Before closing the upper inch of the wound it is desirable to pass a small sponge held by torsion forceps into the peritoneal cavity in order to remove any blood or clot that may be present. The peritoneum is next closed by a continuous fine silk suture. It is well to pass the first stitch throngh the peritoneum on the side next the operator, then through the uterus, and, lastly, through the peritoneum on the opposite side. In this way the peritoneum is brought into accurate apposition with the serous coat of the uterus and prevents a subsequent site for ventral hernia. The recti muscles in the upper portion of the wound are then brought together by another continuous fine silk suture and the skin wound closed in the same manner. Iodoform gauze is applied. The first dressing is removed on the eighth day and the suture on the twelfth day. The patient is allowed out of bed on the fourteenth day.

There is one essential in the closure of this or any abdominal wound, and that is that no pocket must be lef for the accumnlation of serum or blood, for where these factors are thither staphylococci and other micro-organisms gather together-nay, more, thrive.

Buenos Ayres.

\section{A (ASE OF AXIAL ROTATION OF THE TESTIS}

BY A L F R E SHE EN, M.D. ST. AND., SEYIOR SLMIiLOY 'TO THE CARDIFF INLIRMART.

A you'l aged eighteen years jumped over a hedge after a tennis-ball on July 5th, 1895, but felt no ill-effect at the time. On the 6 th at 3 A.M. he awoke with severe pain and swelling in the testicle, it being all right when he went to bed. I saw him on the 9 th in consultation, when the testicle was found to be considerably enlarged and somewhat tender. The temperature was normal although it had been up to $103^{\circ} \mathrm{F}$. I advised immediate incision into the tunica vaginalis to relieve tension, and this was done at the Private Hospital at Cardiff on the 11th. On operation I found a dark-red mass like blood-clot, but not removable, and the testicle was swollen to the size of a small orange, globular in shape. All antiseptic precautions were carried out. The case pursued an aseptic course, the temperature being normal throughout. The stitches, however, gave way and a hernia of the testis resulted ; there was no pain. The dead tissue was dry and was cut away with scissors. There was no sensation, common or testicular. It was obvious that the testicle was useless and it was removed on Aug. 9th ; on the 20 th the wound was dressed for the first time and the stitches were removed, the parts being nearly healed. The patient got $u$ ) for a time day by clay, was out for the first time on the $28 \mathrm{th}$, and went home to London about the middle of September.

The specimen was sent up to the Clinical Research Association and they returned the following report:-" The specimen is an example of that rare condition described as torsion of the testis. The substance of the body of the testicle is healthy in itself; there are no signs of chronic inflammation, syphilis, or tubercle. Section of the epididy. mis shows an abundant extravasation of blood into its tissue, but there is no other lesion. This hæmorrhagic infiltration is due to twisting of the spermatic cord and 